\title{
Theories of Human Rights: Political or Orthodox - why it matters ${ }^{1}$
}

Approximately as appears in Moral and Political Conceptions of Human Rights: Implications for Theory and Practice Reidar Maliks and Johan S. Karlsson, eds. Cambridge, Cambridge University Press (2017), 77-96.

\section{Introduction}

One important contribution by a philosophical theory of international legal human rights [ILHR] is to provide normative perspectives and standards to assess the current international human rights regimes. These regimes include treaties, international human rights courts and treaty bodies, their practices of treaty interpretation and application of ILHR, and their interplay with domestic bodies, other international institutions, and civil society organizations. Such normative perspectives and standards may serve several tasks. Firstly, state authorities, international institutions, citizens and other compliance constituencies can use them to determine the legitimacy of the international human rights regime in general, or a particular legal norm or judgment. Normative standards of this sort can also guide the parties when treaties are negotiated, criticized and changed; and whether new treaties and protocols should be established, e.g. to regulate the legal rights and obligations of further actors - such as multinational corporations - and whether rights against such actors should be called 'human rights.'

Philosophical theories of ILHR also serve important roles in the ongoing development of the human rights practices. Judges and other members of these human rights courts and treaty bodies rely on some normative theory, more or less explicit, when they embark on necessary, highly influential yet contested interpretation of the quite vague terms and norms of the treaties (McCrudden 2014). They must draw on some normative premises to interpret the treaties and adjudicate; e.g. when the European Court of Human Right engages in 'dynamic' interpretation (Lemmens 2015), or heeds what the majority of judges agree is an 'emerging European consensus,' (Dzehtsiarou 2015), or when that Court requires a state to redraft particular legislation in specific ways, as part of its 'pilot judgements' (Tsereteli 2015). These judges must interpret norms, and sometimes make new norms. I submit that a more developed normative theory of ILHR may reduce the risk of domination by judges and of state parties. Indeed, this may also reduce the risk that legitimacy talk becoming a means of alienation. Attention to these normative premises may alleviate though not extinguish Koskenniemi's fear that legitimacy talk and normative discussions are attempts "to appropriate the voice of

\footnotetext{
${ }^{1}$ This article was written under the auspices of ERC Advanced Grant 269841 MultiRights - on the Legitimacy of Multi-Level Human Rights Judiciary; and partly supported by the Research Council of Norway through its Centres of Excellence Funding Scheme, project number 223274 - PluriCourts The Legitimacy of the International Judiciary.

The first version was presented at an invited Session on Theories of Human Rights: Political or Moral - and why it matters when assessing international human rights courts, at the World Congress of Philosophy Athens 4-10 August 2013. I am grateful to the participants and comments and discussions there, from Jürgen Habermas, Reidar Maliks, James W. Nickel, and John Tasioulas.
} 
international legality to a fully instrumentalist discipline dedicated to serving the interests of power." (Koskenniemi 2009, 395)

There is currently a discussion about how two families of theories may best be used to develop such a philosophical theory of ILHR. They both hold as one desideratum of their accounts that their theory must somehow and to some extent match the current international legal human rights regime. "Orthodox" philosophical accounts primarily consider the appropriate way to think of the concept of a human right. These accounts (which include Griffin 2009, Tasioulas 2012c) tend to hold that behind the human rights movement generally - including ILHR - there is a unitary, cogent notion of moral human rights that "constitutes the primary ethical idea driving this movement, giving it both conceptual coherence and normative force" (Tasioulas 2013, 2). Assessment of ILHR is partly done by laying out the implications of these moral human rights for such international institutions. Such moral human rights, claim Orthodox theorists, provide a necessary foundation for a sound theory of ILHR. That is, the same understanding of moral human rights is appropriate as a normative premise and touchstone for ILHR as for other situations where human rights are discussed.

"Political" theories pursue another aim and justificatory strategy. They aspire to systematize the existing international legal human rights practice, and seek to end with a theory with sufficient critical standards, - without drawing on a prior concept of a human right. Representatives of such Political theories typically hold that "the distinctive nature of human rights is to be understood in light of their role or function in modern international political practice." (Cruft et al. 2015, 6; Beitz 2009; Buchanan 2013, 27; cf. Rawls 1999). The ILHR are interpreted as standards for various forms of international expressions of concern - by states, NGOs and other international organizations - about how states treat persons on their territory. Such Political theories are 'non-foundational' in ways that may foster at least two fears: Even when they succeed in bringing coherence that is not enough of a normative foundation to these institutional practices. Moreover, and they may not provide sufficient critical distance to the current practice. Either flaw may render Political theories apologetic comforters for illegitimate human rights institutions, their mandate or particular policies.

The aspiration of Political theories to address ILHR as a primary subject of analysis is thus different from the Orthodox theory perspective. The latter rejects attempts to

conceptually bind human rights to particular institutional structures, such as the state system, or kinds of relations and interactions within them, such as intervention. Instead, the Orthodox View offers us a picture of human right as intermediate moral principles: mediating between the fundamental values (if any) that ground them, on the one hand, and the institutional and social structures that implement them, on the other. (Tasioulas 2012a, 57)

Several authors have argued that alleged conflicts between such Orthodox and Political theories are overdrawn. For instance, Orthodox authors deny that such theories hold that justifiable ILHR must 'mirror' moral human rights, pace Buchanan (Buchanan 2013, 15). Indeed, some hold that Political accounts may permit or even require premises drawn from Orthodox accounts (Valentini 2012, Liao et al. 2012). 
The aim of this article is primarily to alleviate some of these alleged conflicts, in particular to defend at least one Political theory against charges that it is unduly constrained to actual consensus on premises in defense of ILHR, that it is too closely linked to the current state system to match the universal ambitions of human rights, and that it seeks to avoid normative premises. The last section question the alleged value added of Orthodox theories' "intermediate moral principles" of moral human rights for Political theories of ILHR.

To fix ideas, section 1 lays out some relevant aspects of an Orthodox account, mainly drawing on Tasioulas' theory. Section 2 sketches parts of one 'global' political theory of ILHR which avoids some criticism against other Political theories. Section 3 draws on the theory of reflective equilibrium for justification in normative theory, arguing that both Orthodox and Political theories may be understood to fit this account, - in ways which reduce their apparent disagreements. That background also allows us in Section 4 to explore the roles of the concept of 'human dignity' within this global Political theory. The section addresses some concerns that Political theories seek to avoid normative premises, and explores the case for 'Global Public Reason' as regards ILHR. Section 5 challenges claims that Orthodox accounts provide certain necessary supplements to Political theories. The 'intermediate moral principles' of human right provided by Orthodox theories are not of particular help, nor can that theory easily identify which individuals' interests are relevant (Liao and Etinson 2012).

\section{An Orthodox account}

Orthodox theories of human rights seek to elaborate a concept of human rights understood as moral rights that all humans possess by virtue of our humanity. These theories rely on a broad range of premises drawn from ordinary, 'natural' moral reasoning. Tasioulas lays out such an account in several illuminating contributions. Central features are the following:

human rights are moral rights, possessed by all human beings, simply in virtue of their humanity. In other words, human rights, like natural rights, are universal moral rights. Call this the universality thesis. Second, human rights are to be identified by the use of natural reason, principally ordinary, truthoriented moral reasoning, as opposed to the artificial reason of some institution, such as law, the conventionally accepted reasons upheld by some culture or tradition, or the deliverances of divine revelation. Moreover, it is important to stress that ordinary moral reasoning, in virtue of being "natural," need not be saddled with the futile ambition of wringing moral conclusions exclusively from value-free propositions about the natural world. Call this the natural reason thesis. (Tasioulas 2013, 2-3).

The moral human rights are further identified on the basis of a normative premise, that a certain set of interests of great importance to the individual merit overriding concern and respect. Different Orthodox theories vary in how they identify and justify this set of overriding interests. Griffin understands "human rights as protections of our normative agency" (Griffin 2009, 9; cf Ignatieff 2001, 57). Some hold that the relevant form of agency leaves the scope of options and ability to reason 
too indeterminate ( $\operatorname{Raz} 2010)$. It is also unclear why this interest in protection justifies not only rights, but human rights of an overriding and unconditional kind. (Tasioulas 2010). In contrast, Tasioulas justifies moral human rights from two main grounding values:

... they incorporate both the notion of human dignity - the equal intrinsic objective worth of all human beings - and the diverse elements of a flourishing human life, or universal human interests. (Tasioulas 2012c, 7)

For our purposes it is important that this "concept of human rights" justified on Orthodox accounts are somewhat independent of institutions in one or more of three senses.

Many institutions can be understood and justified purely as instrumental, as bundles of legal rules established to carry out our individual obligations in response to these moral human rights. Thus we have obligations e.g. to not commit or contribute to torture or slavery - quite independent of the existence of institutions. Tasioulas notes that for other moral human rights the institutional setting of the individual may be part of the background in considering which human rights the individual has, - e.g. to a fair trial, or democratic political rights. Thus the Orthodox account does not assume that all human rights exist in a state of nature, independent of institutions. But this institutional setting is said to not be part of the "concept" of human rights. I submit that the relationship between the 'concept' of human rights and the institutional 'context' which apparently is not part of that concept remains unclear.

Secondly, human rights are non-conditional. Individuals enjoy them due to human features (almost) universally shared, and institutions may not make human rights conditional on the individual's conduct, performance or membership.

Thirdly, such accounts may serve as critical standards to assess any existing institutions - including the international and regional human rights conventions, courts and treaty bodies.

Orthodox theories seek to give an account of human rights as a moral concept, a concept which in turn will provide possibly a justification as well as criteria for critical assessment of ILHR. Orthodox theories do not aspire to provide a full account of ILHR. In contrast, Political theories typically have that as a central subject matter.

\section{A global Political Theory of Human Rights}

Political and Orthodox theories of human rights share several features. They are meant to serve as critical standards to assess existing institutions. At the risk of creating some tension with that objective, theorists across the Orthodox - Political divide also hold as one desideratum that their theory must to some extent match the current international legal human rights regime. For Political theories, this requirement is a central concern. These theories typically hold that the social function of ILHR is central to develop a satisfactory theory about ILHR: "the distinctive nature of human rights is to be understood in light of their role or function in modern international political practice." (Cruft et al. 2015, 6).

Such Political theories often claim that in our present world order, ILHR should be 
interpreted and assessed as normative conditions on the legitimate exercise of state sovereignty in some sense (Raz 2010; Rawls 1993a; Beitz 2009). Typically, violations of ILHR are matters of international institutional concern (Beitz 2009, 137). Such expressions of concern need not be enforced sanctions or military intervention: they may be diplomatic notes, state obligations to give accounts to treaty bodies, or adjudication by an international court or tribunal. As a matter of international law, a few such measures are already in place, especially among states that have agreed to be subject to the ILHR of various human rights treaties.

Some critics claim that Political theories are too committed to the state system to acknowledge the universality of human rights. Note that the global Political theory of ILHR laid out here is not state centric.

It allows that the current state centric world order and the focus on states' obligations are special cases for such a theory in at least two ways. For clarification let us think of the 'Global Basic Structure' [GBS] as rules and institutions which structure individuals' actions and shared practices. A GBS could be constituted in various ways: as a world federation, or of political units existing in complete anarchy amongst themselves, or as is the case now: populated by a set of quite sovereign states within a web of international practices. Those who deny that there is such a GBS may leave out the following paragraphs without much loss to the argument (cf Follesdal 2011, pace Freeman 2006, Nagel 2005).

Note firstly that this global institutional account allows that ILHR may play a role also in a GBS which is not as state centric as ours. Thus, the roles and thus contents of ILHR may be quite different in a different world order, e.g. in one closer to a world federation of less sovereign states, where the corrective role of more centralized bodies might be similar to that within federations (Zuckert 1996). The contents of IHR will vary with the institutions actually in place, the risks they pose, and the opportunities and risks of international or regional human rights machinery. For instance, in a state system, states are more salient as holders of obligations than are many other actors. Yet this global institutional theory of human rights does not hold that states are necessarily prime obligation holders in principle.

Thus in our present world order where states play prominent roles, I submit that our GBS includes domestic basic structures, as well as an international basic structure which includes international law and treaties, and the courts, tribunals and other bodies they establish. Within this broad account, ILHR are rules which require other bodies to monitor and possibly secure the satisfaction of a range of interests which some bodies - namely states - have primary obligations to secure. In other conceivable GBS, there might be similar justifications for other ILHR that regulate concern among the constituent legal units. On this point this account - and the Orthodox account - thus agrees with Raz that

human rights are synchronically universal. They are rights which all people living today have, a feature that is a precondition of, and a result of, the fact that they set limits to state sovereignty and justify accountability across borders. (Raz 2010, 31)

Secondly, I submit that ILHR are a special case in that they are as yet incomplete, possibly to be supplemented by more forms of trans-national institutional concern that regulate various non-state actors. Within our world order where states are 
important yet not the only and dominant actors, ILHR may serve other yet similar functions in monitoring powerful non-state actors and authorities such as multinational corporations, guerrilla movements or religious organizations; partly because in our world order states are not the only significant players which may protect and threaten IHR. Thus other actors than states may have obligations to be monitored and supported by transnational actors, as regard human rights, such as international organizations and transnational corporations. I submit that this sketch is compatible in broad strokes with the accounts offered by Lafont and Salomon (Lafont 2012, Salomon 2008).

One implication is that this global institutionalist theory can provide an indication of what unites human rights claims held against states and non-state actors: that some interests of individuals at stake are significantly better respected and promoted by some such trans-national institutionalized concerns. It thus bears some resemblance to Beitz' view, that the distinguishing feature of human rights practices is that each interest thus protected is "intersubjectively recognizable as important or urgent" (Beitz 2009, 139) so much that it is "a suitable object of international concern" (ibid 140 ). However, in principle other bodies than states may bear responsibilities regarding the human rights, if necessary to protect and promote these interests. And the nature of these interests merits closer attention.

Even though the Orthodox and the Political theories thus have separate or only partially overlapping subject matters, they stand in some tension.

Firstly, Political theories hold that the substantive contents of such ILHR are contingent on institutions in very complex ways. The content is partly affected by the fact that our legal and political world order consists not only of somewhat sovereign states, but also of domestic, regional and inter-national bodies that interpret, monitor and assess ILHR, in very complex relationships. Thus many regional or international bodies which interpret and adjudicate ILHR serve corrective, supportive or otherwise complementary functions relative to domestic judiciaries (Spano 2014, Shelton 2006, Carozza 2003, Follesdal 2016, Besson 2015, 45). The substantive content of such ILHR depends crucially on this complex institutional interplay.

Orthodox theories allow that legal human rights may somehow be defined in light of such institutions. In particular, they do not assume that such human rights must be based on individuals regarded as atomistic, "isolated from his [sic] fellows... but from reflection on the right ordering of human relationships in emerging societies" (Tierney 1997, 70, quoted by Tasioulas 2012b). Individuals' moral human rights may justify legal human rights which cannot plausibly be regarded as claims that exist "independent" of institutions, such as rights to influence legislation, or rights to a fair trial. Orthodox theories may grant that premises concerning these institutional practices affect the substantive contents of ILHR. Human rights as moral standards must be implemented (as Finnis translates 'determinatio' Finnis 1980, 284), or specified for the more concrete settings.

However, the process appears to be far more complex than the term 'implementation' suggest. Whether inhabitants of a state have an ILHR to a fair trial or to democratic participation requires two important kinds of normative arguments: firstly whether there should be such domestic institutionalized legal rights to secure and promote individuals' relevant interests within complex decision making 
institutions. A second step is also required: to determine which such legal rights should be a matter for transnational institutional concern - for instance by international courts which monitor such domestic political and procedural rights. Political theories may claim that the requisite elaboration of ILHR to be monitored by international courts in complex interplay with domestic institutions is not properly captured by envisioning a 'core' of moral human rights which is specified: the institutional interplay and division of labour have more profound impact on the substantive contents of the ILHR.

To illustrate, a central condition for an ILHR is that some form of international concern will reliably provide helpful safeguards or other service to certain interests of individuals. Note that the service that ILHR provide may be to mobilize other actors than states - e.g. NGOs, domestic parliaments, media or the political opposition. Several scholars have underscored and explored these important mobilizing roles (Simmons 2009, Dai 2005; Alter 2014). It is part of the Political theory account that there may be such interests or domestic human rights which are not ILHR. For instance, some may argue that the European Convention on Human Rights is appropriately silent on social and economic rights, because a) monitoring and adjudication of such rights by the European Court of Human Rights provides little value added to states which respect the (mainly) civil and political rights protected by that Convention, and b) such license to review creates risks that such authority will be misused by the Court. The argument for an ILHR must thus not only draw on the existence of an important human interest, but also on the benefits reliably provided by international institutional concern within the GBS in place.

A second source of differences among the two approaches is that Political theories may hold that some ILHR protect or promote practice dependent interests and claims. Consider that institutions create new opportunity structures, constrain individuals in new ways, create fundamentally new options, and open up for new forms of dependence and risks of domination, for better and for worse.

Institutionalized practices thus give rise to new claims among those subject to them. For instance, normative claims to equal treatment, non-discrimination, or equal shares are particularly strong among those who participate in a shared practice (Scanlon 1997; Follesdal 2015). ILHR which appear to rest on such bases include rights to fair wages and equal pay for work of equal value; the right to social insurance, and to equal access to higher education (United Nations General Assembly 1966, Art 6, 9 and 13). The content and justification of such practice dependent rights must refer not only to universal human interests and descriptive features of institutions, but also to the peculiar normative claims among individuals who jointly uphold institutions (Sangiovanni 2007). Political theories can therefore hold that the particular subject matter of ILHR give rise to quite distinct normative standards, as compared to human rights considered as a moral concept. Such practice dependent rights may both be rights held against fellow citizens subject to state institutions, and rights held against other individuals who are subject to global legal institutions. In the present world order of states, ILHR arguably help specify the added obligations that arise among individuals who are forced to uphold a system of somewhat sovereign states. They have added claims on one another to ensure that state power is not abused to the detriment of individuals' interests. 
A consequence of this institutional focus of the Political theory merits mention. The human interests that ground ILHR are not simply those that are intersubjectively recognizable as urgent. This account thus differs from Gilabert's and Valentini's approaches -if we take them to be addressing the subject matter of ILHR:

We can, on the other hand, formulate a set of abstract rights concerned with extremely important interests shared by all (or most) human beings, whose protection involves responsibilities for anyone who can affect their satisfaction. (Gilabert 2011, 443, my emphasis)

by a right I mean, with Raz [Raz 1986], an interest weighty enough to place duties on others to respect or protect it. Rights so understood are what Wesley Hohfeld [Hohfeld 1964] called 'claim rights', that is, rights that are always correlative to duties. (Valentini 2012, 181)

The relevant interests of individuals must be specified as those that the international human rights regime can protect. Within a system of states, each of which enjoys large bundles of legal powers and immunities, international human rights are legal standards which regulate what states and other actors may or must do to further promote and protect some of these interests. The justification and identification of ILHR thus require identification of some such interests - duly specified in light of this function; and an argument of comparative benefit: Such ILHR as interpreted and applied by international courts actually enhance these interests, without creating as grave damage to other interests of individuals. Such damages might arise for instance if a right created an unreasonable risk that international or regional human rights courts become new sources of domination. Which interests count as important enough to ground ILHR is a question that can only be answered relative to - and in a sense "internal to" - the institutional arrangement within which they play a role. Contrast this to Tasioulas' Orthodox account:

What counts as 'minimal' can be merely be determined by the fiat of the institutions of ILHR; they themselves will need to be guided by some independent criterion, one that can be appealed to in critically assessing their decisions. Now, for the orthodox theorist, the idea of 'minimalism' will be cashed out in a way that makes ineliminable reference to background moral rights. The first question will be: to what extent does an individual's interest in certain conditions of a good life generate an obligation on the part of others to furnish them with those conditions? (Tasioulas 2017)

\section{Reflective Equilibrium}

In order to address concerns about the role of consensus and of appeals to 'Public Reason' in the Political theories, it helps to recall aspects of a prominent mode of philosophical research on normative issues known as the method of 'Reflective Equilibrium' ('RE'). The method can be traced to Aristotle, but was thus named and elaborated by John Rawls (Rawls 1971).

Three main features are relevant here. The starting points of normative theory building are non-foundational empirical and normative 'considered judgments.' 
These may include empirical information and normative judgments about particular cases and generalizations and principles, such as the effects of opposition parties in ensuring an accountable government, and such principles as equal respect for all humans. The starting points also include "second - order judgments": judgments concerning standards of reasoning, formal requirements on alleged moral principles, etc. In our case, the starting considered judgments concerning human rights include several general principles, such as human dignity, and a cluster of universal human interests. Other such judgments may be the Preamble and articles of the UN Universal Declaration of Human Rights, and various other parts of ILHR.

The method of reflective equilibrium is to modify or reject each component considered judgment, and add new ones, guided by objectives to secure consistency and coherence, and sufficient confidence in the resulting modified judgments. The result is a theory which includes these adjusted judgments within a logical structure without internal inconsistencies.

Thirdly, one of the distinguishing features of this method is that none of these considered judgments are regarded as in principle impervious to change as a result of the process of reflection. That is, any considered judgment is open for modification or rejection when confronted with other considered judgments. If a particular judgment belonging to the original set of judgments is incompatible with a proposed general principle, it may on reflection be modified, or indeed discarded. A principle with some degree of initial credibility can similarly be discounted or modified if it yields conclusions incompatible with several particular judgments and with other general principles or with empirical findings.

Particular judgments and principles are thus justified "from above": from empirical premises, normative principles and second - order principles. Principles and second-order principles can also be justified "from below": by the sets of particular judgments and principles that follow from them.

This theory of justification helps alleviate some disagreements among the Orthodox and Political theories. Several authors claim that Political theories deny the need for normative premises and instead focus exclusively on laying out the international human rights practice. They insist that necessary premises include moral human rights, and human dignity in particular (Luban 2015). Thus Griffin holds that "Do not human rights have their own intrinsically valuable purpose: the protection of human dignity? What more point do human rights need than that?" (Griffin 2009, 7); McCrudden suggests that "the general justifying aim of human rights is the pursuit of human dignity" (McCrudden 2014, 27).

In response, the Global Political theory of ILHR does not deny that human dignity may be included among the considered judgments.

\section{Explicating Dignity}

We should be wary of claims that 'human dignity' should enjoy a privileged, immutable position. There are at least two challenges. One main objection to taking dignity as a central premise is that it is too vague on its own to allow specific conclusions about ILHR. Without denying that dignity may be important, institutionalist theories may instead hold that the role and range of ILHR and the 
theory construction can contribute to explicate that concept itself, and to indicate how institutions should express, protect and promote this value (Quine 1960, 256-61; cf Waldron 2013 for similar views). I submit that this is Rawls' point when he argues that

I believe, however, that while the principles of justice will be effective only if men have a sense of justice and do therefore respect one another, the notion of respect or of the inherent worth of persons is not a suitable basis for arriving at these principles. It is precisely these ideals that call for interpretation. The situation is analogous to that of benevolence: without the principles of right and justice, the aims of benevolence and the requirements of respect are both undefined; they presuppose these principles already independently derived. Once the conception of justice is on hand, however, the ideas of respect and of human dignity can be given a more definite meaning. Among other things, respect for persons is shown by treating them in ways that they can see to be justified. But more than this, it is manifest in the content of the principles to which we appeal. .... The theory of justice provides a rendering of these ideas but we cannot start out from them. There is no way to avoid the complications of the original position, or of some similar construction, if our notions of respect and the natural basis of equality are to be systematically presented. (Rawls 1971, 585-586)

In the following I contribute to the process of reflective equilibrium by exploring one interpretation of the concept 'dignity' in a contractualist vein. The ILHR are regarded as justified on the basis of the human dignity of all by seeking empirical and normative premises that cannot reasonably be rejected by others similarly motivated to seek unrejectable agreement (Scanlon 1998, 162; Beitz 1989, 23).

A second challenge to relying on 'dignity' stems from the plurality of world views, especially globallay. The concern for nonrejectability restricts the domain of premises concerning moral and political values, due to the global pluralism of conceptions of the good life (Rawls 1999). The premises and arguments must thus form part of 'global public reason' in this sense (Rawls 1993b, 252 pp; Cohen 2006, Beitz 2001.

We should distinguish that concern from the added challenge that such contractualist commitments are themselves dismissed by many actors whose compliance is important to secure benefits from ILHR. This commitment to global public reason is not a commitment to limit premises to those that are actually shared. This account should rather

interpret human rights as "common" in a special sense, not as the area of agreement among all existing political doctrines or comprehensive views, but as principles for international affairs that could be accepted by reasonable persons who hold conflicting reasonable conceptions of the good life." (Beitz 2001, 276)

The search for normative principles which cannot be reasonably rejected does not dismiss all premises which do not enjoy actual unanimous consent. Thus it appears Tasioulas is mistaken when holding that 
the core problem with the idea of public reason is the attempt to prescind from the idea that judgments and principles of political morality are to be vindicated at the bar of ordinary truth or natural reason, replacing this with a focus on standards of assessment that are actually shared. (Tasioulas 2013, 5).

The aspiration is rather to include only premises which a range of normative theories can accept.

The borders of the 'reasonable' is contested, and partly dependent on the political tasks at hand - including whether there is actual agreement on what counts as unreasonable grounds for objections. Thus Rawls' Political theory has been roundly criticized for holding that the premises for a law of peoples must be compatible with 'decent' but highly illiberal states (Rawls 1999 ; Pogge 1994, Follesdal 1997). The contractualist commitment should be separate from a related consideration, namely that protection of human interests by means of ILHR may be normatively valuable even within harshly autocratic states that reject a contractualist premise. To bring them on board as subject to and contributors to ILHR treaties and their bodies may enhance valuable interests of their citizens, without imposing unacceptable costs on citizens of more democratic and legitimate states. Thus what counts as 'reasonable' and whose normative consensus is important to consider, will vary across the institutions of concern.

The implications of lack of actual consensus should not be overdrawn. Two alternatives to this Political theory merits elaboration.

Michael Ignatieff has argued that lack of agreement on the contents of human rights should lead to a minimalist list of human rights: The universal commitments implied by human rights can be compatible with a wide variety of ways of living only if the universalism implied is self-consciously minimalist. (Ignatieff 2001, 56).

However, the normative concern for non-rejectability is not mainly about conclusions as regards which human rights individuals have. Rather, the reasonable non-rejectability which should be sought concerns the premises and arguments: which interests of individuals should count, the permissible functions of states in promoting and respecting such interests, and likely impact of international concern of various kinds. Complete unanimity among all existent normative views seems uncalled for: to the contrary, the role of ILHR should rather be shaped in light of some profound disagreements, some of which are reasonable and some of which are not.

To illustrate, consider justifications for democratic rights as part of ILHR. This justification is not based on the value of individuals' interest in self-governance alone. That is a contested component of some but not all conceptions of the good life, to such an extent that it appears unreasonable for this purpose. However, less controversial justifications are available, namely that democratic rights - including freedom of the press and other rights necessary to make electoral control effective are effective means to prevent some standard risks of starvation, and other human rights. Democracies avoid famines (Sen 1999; Sen et al. 1990), and protect and promote other human rights (Christiano 2011). Such arguments for political rights are based on premises that can less easily be dismissed from a 'not unreasonable' position.

A contrasting strategy distinct from the Global Political Theory would 
respond to value pluralism by seeking to excise all normative premises from the theory. Liao and Etinson appear to interprets Rawls' Political theory in this way: they hold that Rawls'

blanket rejection of any attempt to justify the content of human rights in light of philosophical, moral, or religious ideals seems too strong. After all, while some forms of moral reasoning may not be readily shareable (e.g., religious reasoning), some philosophical forms of moral reasoning may in fact be quite shareable. As we have seen, philosophical notions such as human dignity and worth are found in many prominent declarations as well as national constitutions and have been central to the reception of human rights across cultures. (Liao and Etinson 2012, 335)

In response, note that several Political theories - including Rawls' - do not aspire to avoid normative premises. However, these normative premises must at the same time be sufficiently precise to allow some conclusions as regards the normative standards of ILHR; and be permitted by Global Public Reason. Thus Rawls' account is explicitly tailored to be acceptable to 'decent hierarchical societies' that secure 'human rights proper', though not necessarily to rouge states (68).

\section{The Contribution of Orthodox Theories to Political Theories}

The final issue to be addressed is whether Orthodox theories about moral human rigghts provide necessary premises to Political theories, and to the Global Political theory in particular. I shall deny this, both as regards moral human rights and concerning their justification in paramount human interests.

In the Global Political Theory sketched above there is a need to specify some set of interests of human beings which ground claims in the form of ILHR, which the human rights courts and treaty bodies should contribute to protect and promote. However, there is no obvious role for any 'intermediate' moral human rights, which would be the contribution of Orthodox theories. Similarly, the norms Buchanan bases his account on are based on human interests rather than human rights.

Luban appears to disagree:

I agree that moral human rights (on the orthodox conception) and, therefore, IHRL [international human rights law], insofar as it gives effect to those rights to the extent that it is appropriate for individual legal rights in international law to do so, are both importantly grounded in considerations of status equality (or human dignity) and well-being (or universal human interests). But neither of these grounds can play their grounding role unless we are already operating with a conception of universal moral rights. Instead of displacing the idea of a universal moral right, the status egalitarian and wellbeing functions can only contribute to IHRL by presupposing that idea. (Luban 2015)

He argues that mobilization around ILHR requires that individuals must hold that ILHR matter to them morally, e.g. invoking feelings of shame. Luban goes on to argue that " ILHRs are capable of mobilizing shame because they concern themselves with human dignity." But human dignity is not moral human rights. Instead, it is a 
normative premise for such moral human rights. So it is unclear what moral human rights add to the normative commitment to human dignity

Furthermore, the set of human interests relied upon by Orthodox theories are neither to be regarded as the contribution of such theories, nor are these interests obviously appropriate for the Global Political theory.

The Global Political theory would agree with the Preamble of the European Convention on Human Rights, that

the object and purpose of the Convention as an instrument for the protection of individual human beings require that its provisions be interpreted and applied so as to make its safeguards practical and effective."

The object is of course not to protect natural human rights, but human beings. Here there is agreement with Orthodox theories: Tasioulas argues that "paradigmatic human rights systematically protect important human interests", and that his theory "appeals to both human status and the elements of the human good in generating human rights. " (Tasioulas 2013, 6 and 7).

Where the two kinds of theories part ways is the identification and specification of those interests. What the Political theories would appear to require, are some premises concerning certain relevant human interests, suitably identified and specified in light of the peculiar institutional role ILHR play in seeking to promote domestic authorities' protection and promotion of certain rights. These interests must thus be selected and expressed with this function in mind, and constrained by Global Public Reason.

\section{Conclusion:}

These reflections have sought to clarify and defend one 'global' Political theory of international legal human rights against some criticism raised by 'Orthodox' accounts of moral human rights, and to challenge the claim that Orthodox accounts can easily deliver premises which the Political theories require.

The aim has been to defend Political theory against charges that it is unduly constrained to actual consensus on premises in defence of ILHR, that it is too closely linked to the current state system to match the universal ambitions of human rights, and that it seeks to avoid normative premises.

This institutional account holds that the 'political' function these human rights serve has implications for the mode of arguments and the subject matter, - indeed also implications for what counts as relevant and urgent interests. That conclusion is at odds with several authors who hold that Political and Orthodox conceptions can not only be reconciled but indeed that Orthodox theories supplement the Political theory in necessary ways. In particular, some argue that political conceptions are unable to specify the substantive contents of human rights absent some further premises - such as those provided by an Orthodox account concerning important interests (Liao and Etinson 2012).

We may surely agree that more premises are needed that are provided by several of the institutional theories surveyed here. But I submit that the Orthodox set of interests is not obviously an answer to the question of which human interests 
international bodies should be concerned with: the latter must draw on a set of relevant interests which is constructed for this purpose. Some of these interests do not 'exist' independently of institutions, and they are relevant only insofar as international concern of the form provided by international treaties and their bodies may promote their protection and promotion by states.

These notes are of course not addressing these important tasks. To the contrary, I suggest that a specification of these relevant interests must be constructed in part on the basis of detailed understandings of the roles, risks and contributions of national and international institutions and authorities within our global basic structure.

\section{References}

Alter, K. J. (2014). The New Terrain of International Law: International Courts in International Politics, Princeton New Jersey, Princeton University Press.

Beitz, C. R. (1989). Political Equality, Princeton, N.J., Princeton University Press.

Beitz, C. R. (2001). 'Human rights as a common concern'. American Political Science Review, 95: 269-282.

Beitz, C. R. (2009). The Idea of Human Rights, Oxford, Oxford University Press.

Besson, S. (2015). Human rights and constitutional law: Patterns of mutual validation and legitimation. In: CRUFT, R., LIAO, S. M. \& RENZO, M. (eds.) Philosophical foundations of human rights. Oxford: Oxford University Press pp. 279-299.

Buchanan, A. (2013). The heart of human rights, Oxford, Oxford University Press.

Carozza, P. G. (2003). 'Subsidiarity as a structural principle of international human rights law '. American Journal of International Law, 97: 38-79.

Christiano, T. (2011). 'An instrumental argument for a human right to democracy'. Philosophy and Public Affairs, 39: 142-176.

Cohen, J. (2006). Is there a human right to democracy? In: SYPNOWICH, C. (ed.) The egalitarian conscience: Essays in honour of G.A. Cohen. Oxford: Oxford University Press pp. 226-248.

Cruft, R., Liao, S. M. \& Renzo, M. (2015). The philosophical foundations of human rights: an overview. In: CRUFT, R., LIAO, S. M. \& RENZO, M. (eds.) Philosophical foundations of human rights. Oxford: Oxford University Press pp. 144.

Dai, X. (2005). 'Why comply? The domestic constituency mechanism'. International Organization, 59: 363-398.

Dzehtsiarou, K. (2015). European Consensus and the Legitimacy of the Strasbourg Court, Cambridge Cambridge University Press.

Finnis, J. (1980). Natural law and natural rights, Clarendon Law Series, Oxford, Oxford University Press <Imprint: Clarendon>.

Follesdal, A. (1997). The standing of illiberal states: Stability and toleration in John Rawls' "Law of Peoples". In: KOLLER, P. \& PUHL, K. (eds.) Current Issues in Political Philosophy: Justice in Society and World Order. Vienna: Verlag HölderPichler-Tempsky pp. 165-174.

Follesdal, A. (2011). 'The Distributive Justice of a Global Basic Structure: A Category Mistake? '. Politics, Philosophy and Economics, 10: 46-65. $10.1177 / 1470594$ X10396302 
Follesdal, A. (2015). Social Primary Goods. In: MANDLE, J. \& REIDY, D. (eds.) The Cambridge Rawls Lexicon. Cambridge: Cambridge University Press pp. 643-647.

Follesdal, A. (2016). 'Subsidiarity and international human rights courts: respecting self-governance and protecting human rights - or neither? '. Law and Contemporary Problems, 79: 147-163.

Freeman, S. (2006). Distributive justice and The Law of Peoples. In: MARTIN, R. \& REIDY, D. (eds.) Rawls's Law of Peoples: A realistic Utopia? Oxford: Blackwell pp. 243-260.

Gilabert, P. (2011). 'Humanist and political perspectives on human rights'. Political Theory, 39: 439-467.

Griffin, J. (2009). On Human Rights, Oxford, Oxford University Press.

Hohfeld, W. N. (1964). Fundamental legal conceptions as applied in judicial reasoning, New Haven, Yale University Press.

Ignatieff, M. (2001). Human rights as politics and idolatry, Princeton, Princeton University Press.

Koskenniemi, M. (2009). 'Miserable Comforters: International Relations as New Natural Law'. European journal of international relations, 15: 395-422. 10.1177/1354066109338229

Lafont, C. (2012). Global Governance and Human Rights - Spinoza lectures, Amsterdam, Van Gorcum.

Lemmens, P. (2015). The European Court of Human Rights. In: BAERE, G. D. \& WOUTERS, J. (eds.) The Contribution of International and Supranational Courts to the Rule of Law Cheltenham: Elgar Publishing pp. 225-241.

Liao, S. M. \& Etinson, A. (2012). 'Political and Naturalistic Conceptions of Human Rights: A False Polemic?'. Journal of Moral Philosophy, 9: 327-352

Luban, D. (2015). Human Rights Pragmatism and Human Dignity. In: RENZO, M., CRUFT, R. \& LIAO, S. M. (eds.) Philosophical foundations of human rights. Oxford: Oxford University Press pp.

Mccrudden, C. (2014). 'Human Rights: Law, politics and philosophy'. https://www.wzb.eu/sites/default/files/u32/chr_mccrudden_human_rights_law_politi CS_and_philosophy.pdf

Nagel, T. (2005). 'The problem of global justice'. Philosophy and public affairs, 33: 113147.

Pogge, T. W. (1994). 'An egalitarian law of peoples'. Philosophy and Public Affairs, 23: 195-225.

Quine, W. V. O. (1960). Word and Object, Cambridge, Mass., MIT Press.

Rawls, J. (1971). A theory of justice, Cambridge, Mass., Harvard University Press.

Rawls, J. (1993a). Law of Peoples. In: SHUTE, S. \& HURLEY, S. (eds.) On Human Rights: the Oxford Amnesty Lectures 1993. New York: Basic Books pp. 175-216.

Rawls, J. (1993b). Political liberalism, New York, Columbia University Press.

Rawls, J. (1999). The law of peoples, Cambridge, Mass., Harvard University Press.

Raz, J. (1986). The morality of freedom, Oxford, Clarendon Press.

Raz, J. (2010). Human Rights without Foundations. In: BESSON, S. \& TASIOULAS, J. (eds.) The Philosophy of International Law. Oxford: Oxford University Press pp. 321-338.

Salomon, M. E. (2008). Global responsibility for human rights: World poverty and the development of international law, Oxford, Oxford University Press. 
Sangiovanni, A. (2007). 'Justice and the priority of politics to morality'. Journal of Political Philosophy, 16: 137-64. 10.1111/j.1467-9760.2007.00291.x

Scanlon, T. M. (1997). The diversity of objections to inequality. The Lindley Lecture, Lawrence, KS, University of Kansas Press.

Scanlon, T. M. (1998). What we owe to each other, Cambridge, Mass., Harvard University Press.

Sen, A. K. (1999). 'Democracy as a universal value'. Journal of Democracy, 10: 3-17.

Sen, A. K. \& Dréze, J. (1990). Hunger and public action, Oxford University Press.

Shelton, D. (2006). 'Subsidiarity and human rights law'. Human Rights Law Journal, 27: 4-11.

Simmons, B. A. (2009). Mobilizing for Human Rights: International Law in Domestic Politics, New York, Cambridge University Press.

Spano, R. (2014). 'Universality or diversity of human rights? Strasbourg in the age of subsidiarity'. Human Rights Law Review: 1-16. 10.1093/hrlr/ngu021

Tasioulas, J. (2010). 'Taking rights out of human rights'. Ethics, 120: 647-678. $10.1086 / 653432$

Tasioulas, J. (2012a). Human rights: an orthodox view (Chapter 1?). Human Rights [?]. Oxford: Oxford University Press [?] pp.

Tasioulas, J. (2012b). On the nature of human rights. In: ERNST, G. \& HEILINGER, J.C. (eds.) The philosophy of human rights: Contemporary Controversies. Berlin: de Gruyter pp. 17-61.

Tasioulas, J. (2012c). 'Towards a philosophy of human rights'. Current legal problems, 65: $1-30$.

Tasioulas, J. (2013). 'Human rights, legitimacy and international law'. American Journal of Jurisprudence, 58: 1-25.

Tasioulas, J. (2017). Exiting the Hall of Mirrors: Morality and Law in Human Rights. In: CAMPBELL, T. \& BOURNE, K. (eds.) Confronting moral, political and legal approaches to human rights (to appear). London: Routledge pp.

Tierney, B. (1997). The idea of natural rights: Studies on natural rights, natural law and Church law 1150-1625, Grand Rapids/Cambridge, Eerdmans Publishing Company.

Tsereteli, N. (2015). Legal Validity and Legitimacy of the Pilot Judgment Procedure of the European Court of Human Rights, PhD dissertation, Oslo, University of Oslo.

United Nations General Assembly (1966). International covenant on economic, social and cultural rights, General Assembly resolution 2200A (XXI) of 16 December 1966,

Valentini, L. (2012). 'In what Sense Are Human Rights Political?'. Political Studies, 60: 180-94.

Waldron, J. (2013). 'Human Rights: A critique of the Raz/Rawls Approach'. NYU School of Law, Public Law Research Paper No. 13-32

Zuckert, M. P. (1996). Toward a theory of corrective federalism: the United States constitution, federalism, and rights. In: KATZ, E. \& TARR, G. A. (eds.) Federalism and Rights. Lanham, Maryland: Rowman \& Littlefield pp. 76-100. 